\title{
RESPON STRUKTUR DUA DERAJAT KEBEBASAN DENGAN KEKAKUAN SEBAGAI PARAMETER KETIDAKPASTIAN
}

\author{
Olga Pattipawaej ${ }^{[1]}$, Budiarto ${ }^{[2]}$
}

\begin{abstract}
ABSTRAK
Sistem suatu struktur sangatlah bergantung kepada ketidakpastian yang ada di geometri struktur, sifat bahan dan kondisi pembebanan. Pemodelan struktur berupa bangunan dua lantai sebagai portal sederhana berdimensi dua. Dengan memasukkan parameter ketidakpastian, perhitungan dilakukan dengan menggunakan gabungan dua metode yaitu probabilitas dan metode elemen hingga. Parameter ketidakpastian dalam tulisan ini adalah kekakuan struktur. Hasil analisis dengan menggunakan program Matlab diperoleh bahwa pengaruh respon sebelum memasukkan dan setelah memasukkan parameter ketidakpastiannya menyebabkan adanya penambahan perpindahan.
\end{abstract}

Kata kunci : Ketidakpastian, Probabilitas, Metode elemen hingga.

\begin{abstract}
System of structures is very much depending on the uncertainties that embrace in geometry, materials, and loading. A two-story building structure is modeled as a two dimensional of simple portal. Taking account of the uncertainties, the calculation has conducted by using two combining methods that is finite element method and probability. Uncertainties parameter in this article is the stiffness of structure. Analysis result using Matlab program is obtained that influence of response before and after put into the uncertainties cause the existence of the additional displacements.
\end{abstract}

Keywords : Uncertainty, Probability, Finite element method.

\section{PENDAHULUAN}

Tidaklah mudah dan tidak selalu dapat ditemukan solusi matematis yang tepat untuk masalah teknik. Kenyataannya, solusi analitis hanya mungkin untuk beberapa keadaan yang disederhanakan. Untuk masalah mengenai sifat material yang kompleks dan rumit, pembebanan dan syarat-syarat batas, ahli teknik membuat anggapan dan idealisasi yang sesuai sehingga diperoleh penyelesaian matematis yang diperlukan yang dapat memberikan solusi pendekatan dengan hasil yang memuaskan.

Dalam bidang teknik, penerapan praktis yang biasa digunakan dalam menganalisa suatu sistem struktur adalah dengan mengasumsikan parameternya sebagai sesuatu yang pasti atau deterministik. Meskipun dalam situasi yang nyata hal ini tidaklah mungkin terjadi sehingga tanggapan stuktur dan sistem perancangan secara keseluruhan menjadi penting dengan mengikutsertakan parameter ketidakpastian (uncertainty) dalam proses perhitungan. 
Sistem suatu struktur sangatlah bergantung kepada ketidakpastian yang ada di geometri struktur, sifat bahan dan kondisi pembebanan. Ada tiga metode dasar yang digunakan dalam menganalisa tanggapan struktur dengan memperhitungkan paramater tak pastinya, yaitu: Simulasi Monte Carlo, Neuman Ekspansi dan Probability Metoda Elemen Hingga.

Dalam tulisan ini metode yang akan digunakan yaitu probability metoda elemen hingga dengan menggunakan perluasan Deret Taylor derajat dua karena ditinjau dari segi teori dan komputasi sangatlah mungkin diterapkan meski untuk sistem struktur yang besar tetapi tetap menerapkan teknik komputasi biasa. Metode elemen hingga digunakan dengan mengikutsertakan parameter ketidakpastian, sehingga pendekatan ini dikenal juga dengan stokastik metoda elemen hingga (Kleiber dan Hien, 1992). Tujuan tulisan ini dibuat adalah untuk mengetahui perilaku perpindahan akibat dari kekakuan lateral sebagai random variabel atau parameter ketidakpastian terhadap bangunan berlantai dua. Pemodelan bangunan berlantai dua sebagai portal sederhana bertujuan untuk memudahkan perhitungan struktur baik itu massa maupun kekakuan. Sementara damping merupakan kombinasi linier massa dan kekakuan. Gempa El-Centro diikutsertakan untuk mengetahui respons dinamik pembebanan bangunan berlantai 2 dengan riwayat waktu.

\section{PEMODELAN PARAMETER KETIDAKPASTIAN}

Perhitungan dan analisa keberadaan struktur sudah diketahui tidak dapat mengabaikan pengaruh adanya ketidakpastian/uncertainty. Sumber ketidakpastian yang ada di lingkungan dapat dikenal melalui bentuk struktur, parameter bahan dan juga gaya pembebanan yang terjadi. Dengan adanya ketidakpastian ini dan pengaruhnya terhadap suatu struktur menjadi suatu yang sangat penting dalam perhitungan tanggapan dan sistem struktur secara keseluruhan.

Ahli teknik dan peneliti telah menerapkan beberapa metode untuk menjawab masalah ini. Metoda tradisional yang sangat sering dilakukan adalah mengabaikan variasi suatu variabel. Metode ini mengasumsikan bahwa kemungkinan terburuk dari suatu variabel digunakan sebagai nilai masukkan/input. Akibatnya analisa suatu struktur hanya berdasarkan nilai-nilai parameter yang pasti saja/deterministic (Clough dan Penzien, 1993).

Pendekatan lain yang sering digunakan adalah simulasi Monte Carlo (Astill, Nossier dan Shinozuka, 1972). Dalam metoda ini suatu proses statistik digunakan dengan cara melakukan simulasi numerik dari suatu variabel. Simulasi numerik ini menerima masukkan dari suatu kumpulan variabel acak yang ditentukan sebagai nilai yang tidak pasti dalam 
sistem suatu struktur. Analisa lebih lanjut diperlukan untuk memperkirakan besarnya nilai ketidakpastian tersebut. Sayangnya metode ini memerlukan banyak data variabel acak tadi untuk mendapatkan hasil yang baik. Tidaklah mengherankan jika diperlukan banyak pengulangan/iterasi dan kurang efisien jika banyak variabel acak yang diikutsertakan dalam perhitungan.

Aplikasi metoda numerik lain yang lebih efisien dalam bidang teknik adalah probabilistik metoda elemen hingga. Secara umum probabilistik metoda elemen hingga ini merupakan kombinasi dua metode, yaitu metode elemen hingga dan metode probabilitas. Metoda elemen hingga telah dikenal merupakan alat yang sangat sering dipakai dalam bidang teknik terutama dalam memecahkan masalah-masalah yang kompleks. Metode ini memiliki konsep yang sederhana, akurat dalam pemgembangannya dan mempunyai kemampuan aplikasi yang baik. Hasil penggunaan metode elemen hingga ini memerlukan biaya operasi yang terjangkau dan dapat digunakan untuk sistem yang sangat besar yang sangat penting di bidang teknik. Selanjutnya metode probabilitas secara eksplisit memasukkan ketidakpastian yang bersesuaian dengan analisa variabel yang pasti. Nilai eksak dari variabel-variabel ini biasanya tidak diketahui karena tidak dapat diukur secara akurat. Dengan kata lain, probabilistik metode elemen hingga merupakan suatu metode numerik yang mengikutsertakan unsur ketidakpastian dalam memprediksi reaksi suatu struktur.

Banyak peneliti berperan serta dalam pengembangan berbagai aspek metodologi probabilistik metode elemen hingga. Kekuatan utama dari penelitian mereka adalah dengan mengikutsertakan sumber-sumber ketidakpastian (uncertainties) dalam pemodelan dan merumuskan persamaan matematika dari reaksi suatu struktur dengan tetap menggunakan metode elemen hingga.

Ketika teknik elemen hingga digunakan dalam analisa keandalan, mereka biasa menyebutnya sebagai teknik stokastik elemen hingga. Hal ini dikarenakan gambaran parameter suatu struktur dimodelkan sebagai variabel acak. Pendekatan komputasi berdasarkan formula pembebanan diterapkan dan digunakan bersamaan dengan analisa stokastik elemen hingga untuk memprediksi kemungkinan terjadi kegagalan suatu struktur yang kompleks (Guan dan Melchers, 1999).

Vanmarcke and Grigoriu (1983) menganalisa beam satu dimensi dengan probabilistik metode elemen hingga. Metode yang diterapkan digambarkan dengan menghitung lendutan statis suatu beam dimana kekakuannya bervariasi sepanjang sumbunya. Chakraborty and Dey (1995) menerapkan stokastik metode elemen hingga untuk 
menganalisa suatu balok kantilever dimana kelenturan dan pembebanan merata dimodelkan sebagai proses Gauss yang homogen berdimensi satu. Teknik perluasan Neumann digunakan sebagai invers dari stokastik matrik kekakuan dalam mencari reaksi solusi elemen hingga. Mereka juga menerapkan metode ini untuk menganalisa struktur dinamik dengan pembebanan acak. Reaksi dinamika terhadap beban harmonik yang umum seperti beban gempa yang diperoleh melalui domain frekuensi. Selanjutnya Lei and Qui (2000a) juga menggunakan dinamika Neumann stokastik metode elemen hingga dalam domain waktu untuk menganalisa dinamika respon suatu struktur.

Selain ekpansi Neumann, pendekatan perturbasi digunakan dalam mempelajari pengaruh dinamika ketidakpastian struktur dimana pembebanannya dapat acak atau pasti. Khusunya, Ghanem menyajikan hal-hal utama pengembangan umum spektral stokastik metode elemen hingga. Metode ini kemudian dikembangkan sebagai perbandingan dari perkembangan metode elemen hingga biasa, yang digunakan dalam tulisan Ghanem dan Kruger (1996).

Aplikasi dari perturbasi berdasarkan stokastik metode elemen hingga telah digunakan dalam analisa kelelahan/fatigue dari media yang homogen dan heterogen (Kaminski 2002). Lee and Lim (1998) mengerjakan langkah-langkah yang lebih sederhana untuk optimasi perancangan bersamaan dengan sistem suatu struktur acak. Dalam prosedurnya, metode perturbasi orde dua diterapkan dalam menghitung tekanan dan perpindahan. Dalam pendekatan perturbasi, perhitungan kepekaan suatu perancangan dari suatu sistem acaknya dinyatakan sebagai jumlah komponen pasti/deterministik dan tak pasti/acak. Lei and Qiu (1998) mempelajari kemampuan dinamika stokastik metode elemen hingga berdasarkan dinamika pembatasan mode dan mengevaluasinya melalui hasil suatu beam sederhana dan suatu rangka struktur dengan pembebanan gempa. Nonlinier dipertimbangkan dalam penggunaan metode di atas sebagai penelitian lanjut.

\section{DESAIN GEDUNG LANTAI DUA}

Studi kasus menggunakan model gedung dengan sistem struktur balok-kolom dengan jumlah lantai dua. Mutu beton yang digunakan adalah $f_{c},=25$ MPa dan $f_{y}=400$ MPa. Pelat menggunakan tebal $120 \mathrm{~mm}$. Penutup atap menggunakan pelat dak dengan tebal $120 \mathrm{~mm}$. Pada pemodelan struktur, data-data yang digunakan data-data dari gedung berlantai dua dengan tinjauan portal dua dimensi. Lantai pada pemodelan ini ditetapkan sebagai rigid diaphragm, yaitu massa dipusatkan pada satu titik nodal untuk tiap lantainya. Denah untuk lantai 1 dan 2 dan potongan portal dapat dilihat pada Gambar 1. 


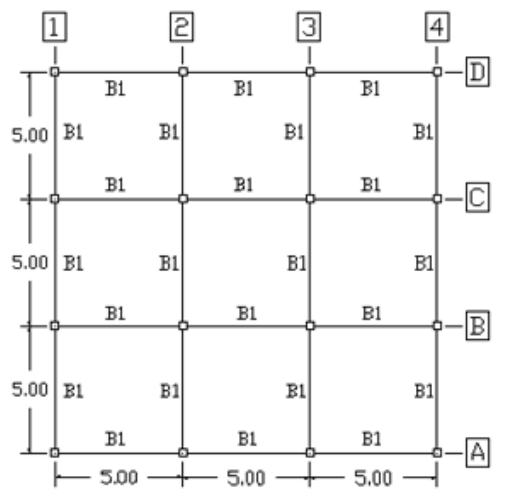

(a)

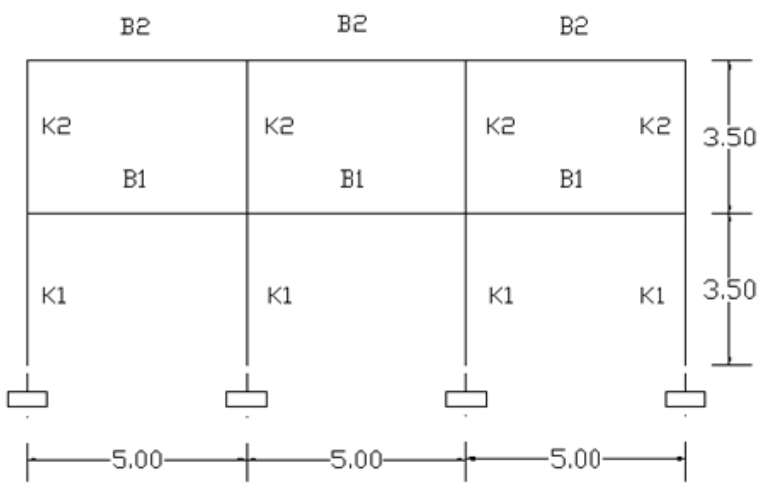

(b)

Gambar 1. (a) Denah lantai 1 dan lantai 2; (b) Potongan portal B

Pembebanan yang digunakan pada struktur gedung tersebut hanya beban mati (DL), beban hidup (LL) dan beban mati tambahan (SDL), dimana beban-beban tersebut, dimaksudkan untuk mendapatkan suatu besaran dari kekakuan, massa dan redaman dari struktur gedung itu tersebut. Hasil perhitungan beban mati pada struktur sebesar $386 \mathrm{~kg} / \mathrm{m}^{2}$ untuk lantai 1 dan 2, sedangkan beban mati untuk dak sebesar $299 \mathrm{~kg} / \mathrm{m}^{2}$. Beban hidup pada struktur sebesar $250 \mathrm{~kg} / \mathrm{m}^{2}$ untuk lantai 1 dan 2, sedangkan dak sebesar $100 \mathrm{~kg} / \mathrm{m}^{2}$. Perhitungan ekivalen beban diatas merupakan perhitungan pembebanan pada pelat lantai maupun dak.

Massa terpusat pada titik hubung elemen struktural. Massa secara proporsional dengan beban gravitasi, yaitu :

$$
\mathrm{m}=\frac{\mathrm{W}}{\mathrm{g}}
$$

dimana $\mathrm{W}$ adalah berat bangunan per lantai dan g percepatan gravitasi.

Dalam dinamika struktur (Paz, 1990), jumlah koordinat bebas diperlukan untuk menetapkan susunan atau posisi sistem pada setiap saat, yang berhubungan dengan jumlah derajat-kebebasan (degrees of freedom).

Pada umumnya struktur berkesinambungan (continuous structure) mempunyai jumlah derajat kebebasan (number of degrees of freedom) tak berhingga. Namun dengan proses idealisasi atau seleksi, sebuah model matematis yang tepat dapat mereduksi jumlah derajat kebebasan menjadi suatu jumlah diskrit. 
Pada penelitian ini, gedung dianggap sebagai struktur berderajat kebebasan dua. Secara umum, persamaan matriks massa $[\mathrm{M}]=\left[\begin{array}{ll}\mathrm{m}_{1} & 0 \\ 0 & \mathrm{~m}_{2}\end{array}\right]=\left[\begin{array}{cc}19044,75025 & 0 \\ 0 & 18890,62181\end{array}\right] \mathrm{kg}$ $\operatorname{det}^{2} / \mathrm{m}$, dimana $\mathrm{m}_{1}$ adalah massa lantai 1 dan $\mathrm{m}_{2}$ merupakan massa lantai 2 .

Kekakuan suatu struktur adalah gaya yang dapat disimpan oleh sistem struktur bila struktur itu diberi perpindahan baik itu perpanjangan, perpendekan, perputaran sudut, atau deformasi - deformasi lainnya.

Kekakuan merupakan gaya balik elastic (elastic restoring force) dan kapasitas energi potensial dari struktur. Persamaan kekakuan yang digunakanuntuk sebuah kolom bermassa seragam dengan kedua ujungnya terjepit atau tak berotasi, konstanta pegasnya adalah,

$$
\mathrm{K}=\frac{12 \times \mathrm{E} \times \mathrm{I}}{\mathrm{h}^{3}}
$$

dengan h tinggi total kolom per lantai, E adalah modulus elastisitas dan I momen inersia. Sedangkan persamaan matriks kekakuan,

$$
[K]=\left[\begin{array}{ll}
k_{1}+k_{2} & -k_{2} \\
-k_{2} & k_{2}
\end{array}\right]=\left[\begin{array}{cc}
3551720,116 & -1775860,058 \\
-1775860,058 & 1775860,058
\end{array}\right] \mathrm{kg} / \mathrm{m}
$$

dengan $\mathrm{k}_{1}$ kekakuan lantai 1 dan $\mathrm{k}_{2}$ kekakuan lantai 2.

Redaman pada suatu struktur yang bergetar menyatakan adanya fenomena disipasi energi atau penyerapan energi.

Salah satu contoh bila struktur digetarkan semakin lama amplitudonya semakin kecil hingga akhirnya struktur itu diam. Redaman struktur dimodelkan sama dengan redaman viscous yaitu besarnya gaya redaman yang dialami oleh suatu struktur yang bergetar berbanding lurus dengan koefisien redaman serta kecepatan getaran struktur.

Model redaman yang digunakan pada perhitungan ini menggunakan redaman Rayleigh sebagai berikut

$$
[C]=\alpha[M]+\beta[K]=\left[\begin{array}{ll}
24653,41932 & -8204,47346 \\
-8204,47346 & 16382,22365
\end{array}\right] \mathrm{kg} \mathrm{det} / \mathrm{m}
$$

dimana $[\mathrm{C}]$ matriks redaman, $[\mathrm{M}]$ matriks massa dan $[\mathrm{K}]$ : matriks kekakuan. 
Koefisien $\alpha$ adalah koefisien redaman yang tergantung massa dan koefisien $\beta$ adalah koefisien redaman yang berhubungan dengan kekakuan, yang dihitung untuk memberikan tingkat yang dibutuhkan redaman viscous pada dua frekuensi yang berbeda, didapat dari nilai mode pertama dan mode kedua dari vibrasi bebas.

\section{BEBAN GEMPA}

Dalam hal pengaruh gempa pada struktur gedung ditentukan berdasarkan suatu analisa dinamik, maka yang diartikan dalam beban gempa disini adalah gaya-gaya didalam struktur tersebut yang terjadi oleh gerakan tanah akibat gempa itu. Peninjauan arah gempa menggunakan satu arah saja.

Gempa El-Centro terjadi pada tanggal 15 Mei 1940 di dataran California, AS diambil sebagai beban gempa. Pergerakan tanah gempa El-Centro ini berhasil dicatat pertama kali dari lokasi gempa Imperial Valley California, pada jarak 9 km dari pusat gempa, dengan durasi 13,98 detik. Skala gempa 6,4 Richter. Beban ini dipilih karena kecenderungan respons spektra percepatan yang dihasilkan hampir sama dengan hasil penelitian respon spektra percepatan dari gempa-gempa yang ada di Indonesia.

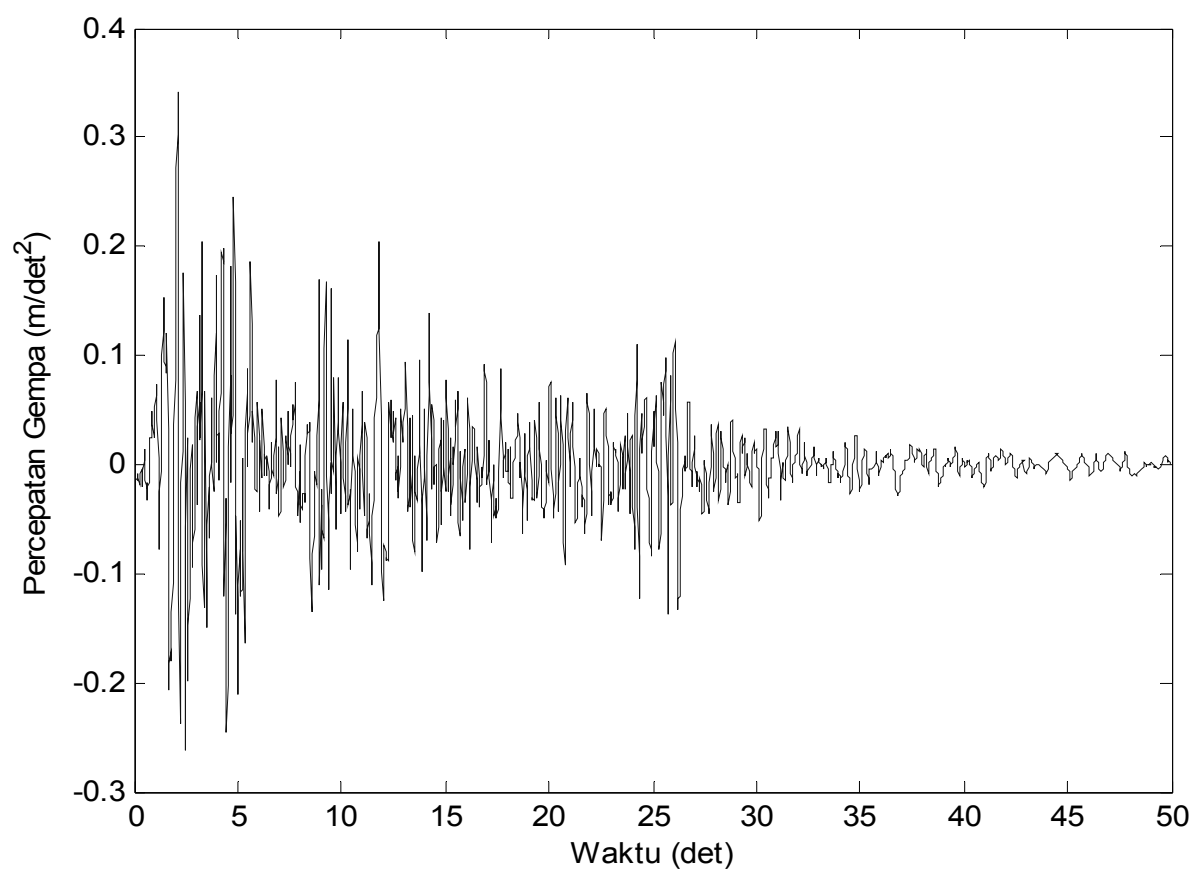

Gambar 2. Akselerogram Gempa El-Centro 1940 N-S

Selain itu tipe beban gempa El-Centro 1940 N-S akan direspon oleh semua ragam struktur, baik kecil, sedang maupun besar. Percepatan tanah maksimum 0,3417g terjadi pada 
detik ke 2,1. Dengan rata-rata sebesar $5,9901 \times 10^{-4}$ dan simpangan standar deviasi sebesar 0,4676 yang diperoleh dari analisis MATLAB. Hasil pencatatan akselerograph dari gempa El-Centro terlihat pada Gambar 2.

\section{PROBABILITAS METODE ELEMEN HINGGA}

Persamaan dinamik dimana gempa merupakan gaya luar dapat dinyatakan sebagai persamaan orde nol sebagai berikut :

$$
\overline{\mathrm{M}} \ddot{\overline{\mathrm{x}}}+\overline{\mathrm{C}} \dot{\overline{\mathrm{X}}}+\overline{\mathrm{K}} \overline{\mathrm{x}}=-\overline{\mathrm{F}}=-\overline{\mathrm{M}} \ddot{\mathrm{U} g}
$$

Dengan mensubstitusikan matriks redaman Rayleigh ke dalam persamaan orde-nol diperoleh

$$
\overline{\mathrm{M}} \ddot{\overline{\mathrm{X}}}+(\alpha \mathrm{M}+\beta \mathrm{K}) \dot{\overline{\mathrm{X}}}+\overline{\mathrm{K}} \overline{\mathrm{x}}=-\overline{\mathrm{F}}=-\overline{\mathrm{M}} \ddot{\mathrm{U} g}
$$

Persamaan (6) merupakan persamaan dinamik umum dimana semua paramaternya deterministik. Dalam tulisan ini, kekakuan diasumsikan sebagai paramater ketidakpastian. Persamaan orde-nol yang diturunkan terhadap fungsi matriks kekakuan yang kemudian disebut sebagai persamaan orde-satu. Penurunan persamaan orde-nol terhadap matriks kekakuan adalah sebagai berikut :

$$
\left.\overline{\mathrm{M}} \frac{\partial \ddot{\mathrm{x}}(\mathrm{t})}{\partial \mathrm{K}}\right|_{\overline{\mathrm{K}}}+\left.\overline{\mathrm{C}} \frac{\partial \dot{\mathrm{x}}(\mathrm{t})}{\partial \mathrm{K}}\right|_{\overline{\mathrm{K}}}+\left.\overline{\mathrm{K}} \frac{\partial \mathrm{x}(\mathrm{t})}{\partial \mathrm{K}}\right|_{\overline{\mathrm{K}}}=\widetilde{\mathrm{F}}
$$

dengan,

$$
\begin{aligned}
& \tilde{F}=\left.\frac{\partial F}{\partial K}\right|_{\bar{K}}-\left[\left.\frac{\partial M}{\partial K}\right|_{\bar{K}} \ddot{\bar{x}}(t)+\left.\frac{\partial C}{\partial K}\right|_{\bar{K}} \dot{\bar{x}}(t)+\left.\frac{\partial K}{\partial K}\right|_{\bar{K}} \bar{x}(t)\right] \\
& \tilde{F}=0-[0-\beta \dot{\bar{x}}(t)+\bar{x}(t)]
\end{aligned}
$$

sehingga diperoleh persamaan orde-satu menjadi :

$$
\widetilde{\mathrm{F}}=\beta \dot{\overline{\mathrm{x}}}(\mathrm{t})+\overline{\mathrm{x}}(\mathrm{t})
$$

Turunan kedua dari persamaan orde-nol terhadap fungsi matriks kekakuan disebut sebagai persamaan orde-dua, dimana persamaannya adalah sebagai berikut :

$$
\overline{\mathrm{M}} \Delta \ddot{\overline{\mathrm{x}}}(\mathrm{t})+\overline{\mathrm{C}} \Delta \dot{\overline{\mathrm{x}}}(\mathrm{t})+\overline{\mathrm{K}} \Delta \overline{\mathrm{x}}(\mathrm{t})=\Delta \hat{\mathrm{F}}(\mathrm{t})
$$

dengan,

$$
\Delta \hat{\mathrm{F}}(\mathrm{t})=\left(\left.\beta \frac{\partial \dot{\overline{\mathrm{x}}}(\mathrm{t})}{\partial \mathrm{K}}\right|_{\overline{\mathrm{K}}}+\left.\frac{\partial \overline{\mathrm{x}}(\mathrm{t})}{\partial \mathrm{K}}\right|_{\overline{\mathrm{K}}}\right) \operatorname{Var}(\mathrm{K})
$$

dengan memasukkan kekakuan sebagai parameter ketidakpastian, respon dinamik untuk perpindahan diperoleh dari penyelesaian persamaan (6) dan (10), yaitu

$$
E(x(t))=x(t)+\Delta x(t)
$$




\section{HASIL}

Analisis dilakukan secara numerik dengan menggunakan program MATLAB. Gambar 3 menunjukkan perpindahan lantai 1 terhadap riwayat waktu untuk orde pertama. Sedangkan Gambar 4 menunjukkan kontribusi perpindahan yang diperoleh dari orde dua.

Simpangan baku perpindahan pada lantai 1 dapat dilihat pada Gambar 5. Tabel 1 menunjukkan hasil respon dinamik gedung lantai 1 akibat beban gempa.

Tabel 1. Respons dinamik akibat beban gempa pada lantai 1

\begin{tabular}{|c|c|c|}
\hline & $0^{\text {th }}($ meter $)$ & $2^{\text {th }}($ meter $)$ \\
\hline Mean & $1,3317 \times 10^{-5}$ & $-1,0935 \times 10^{-5}$ \\
\hline Simpangan Baku & 0,0169 & $3,6774 \times 10^{-5}$ \\
\hline Maksimum & 0,0923 & $1,6909 \times 10^{-4}$ \\
\hline
\end{tabular}

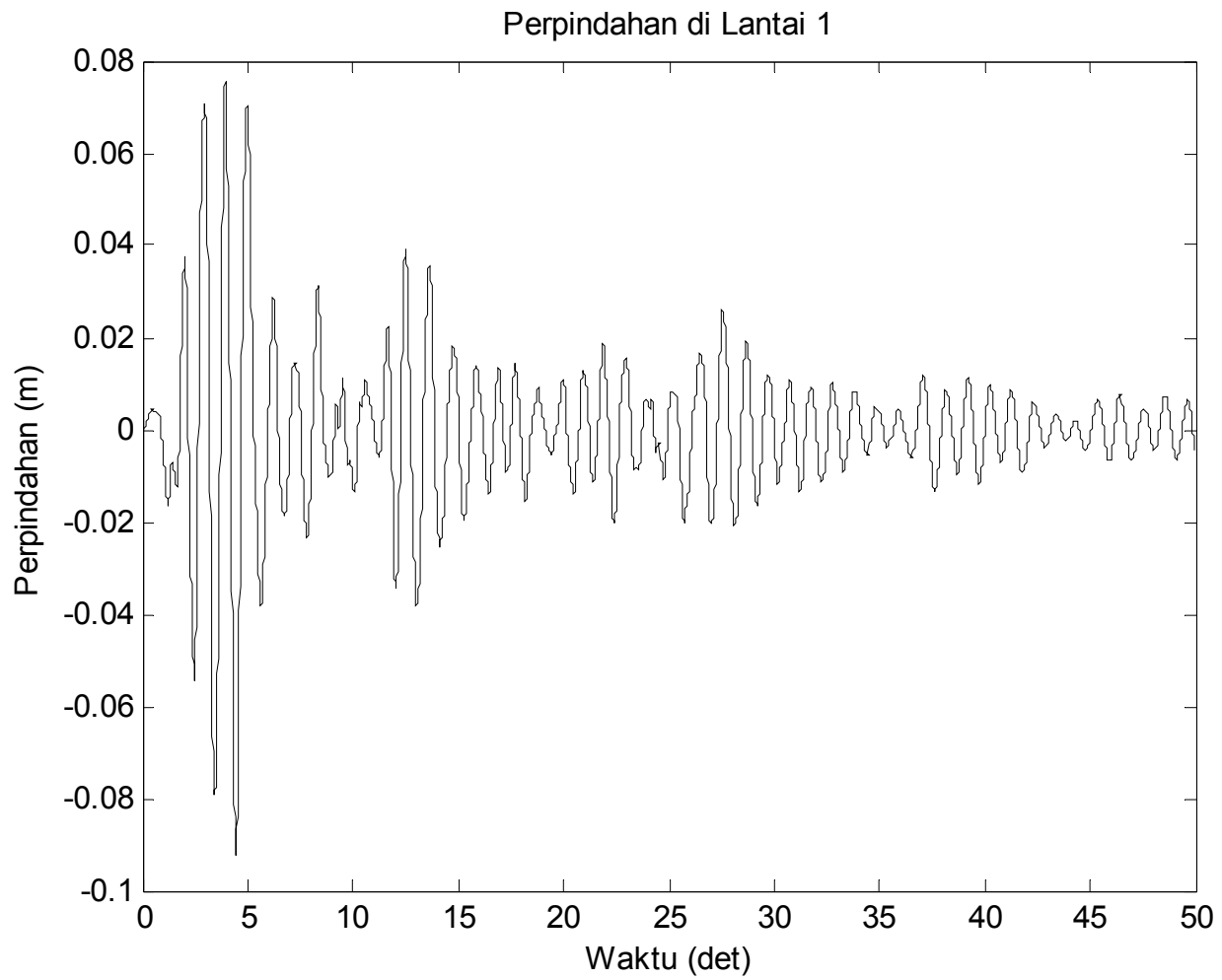

Gambar 3. Perpindahan lantai 1 terhadap riwayat waktu 


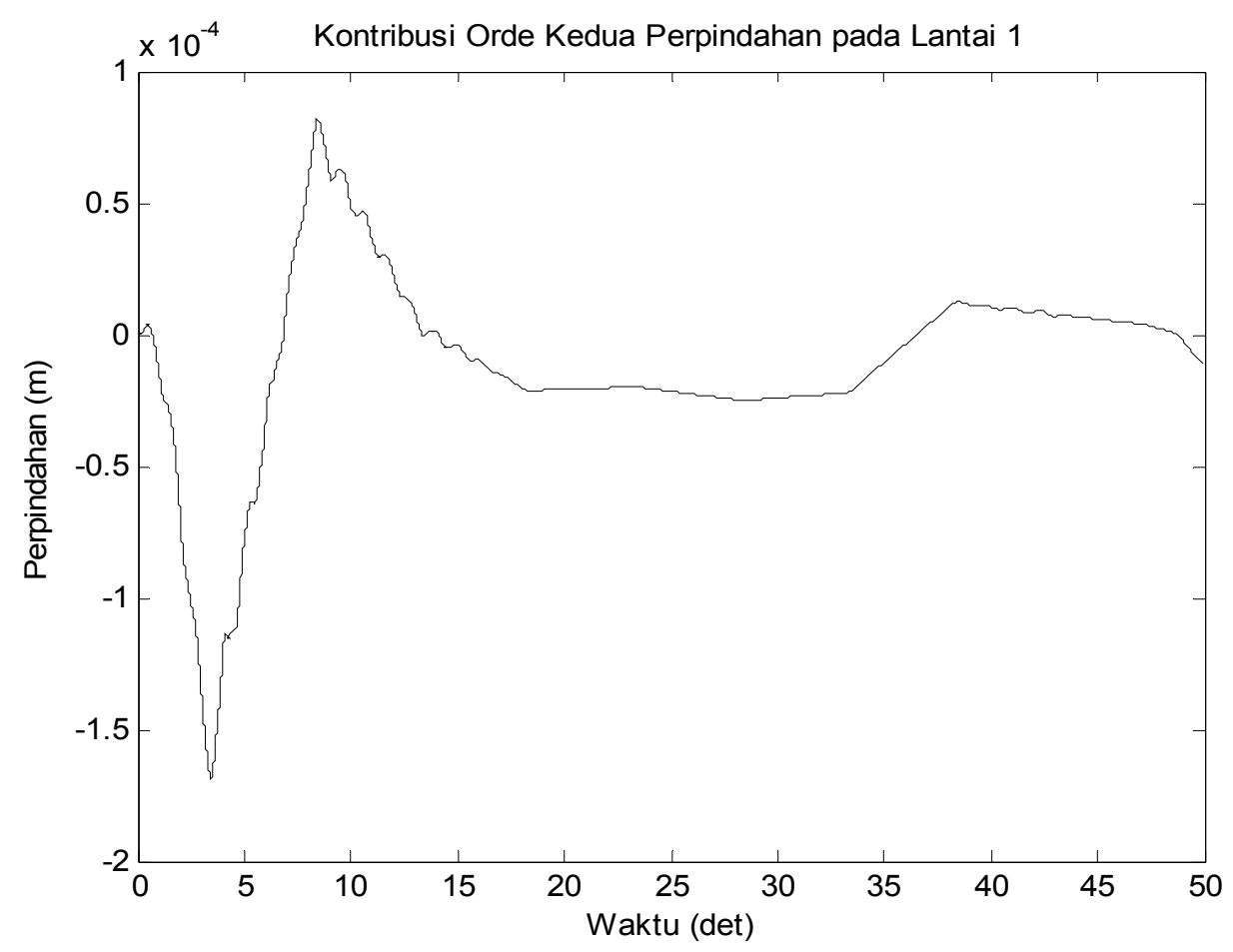

Gambar 4. Kontribusi orde kedua perpindahan di lantai 1

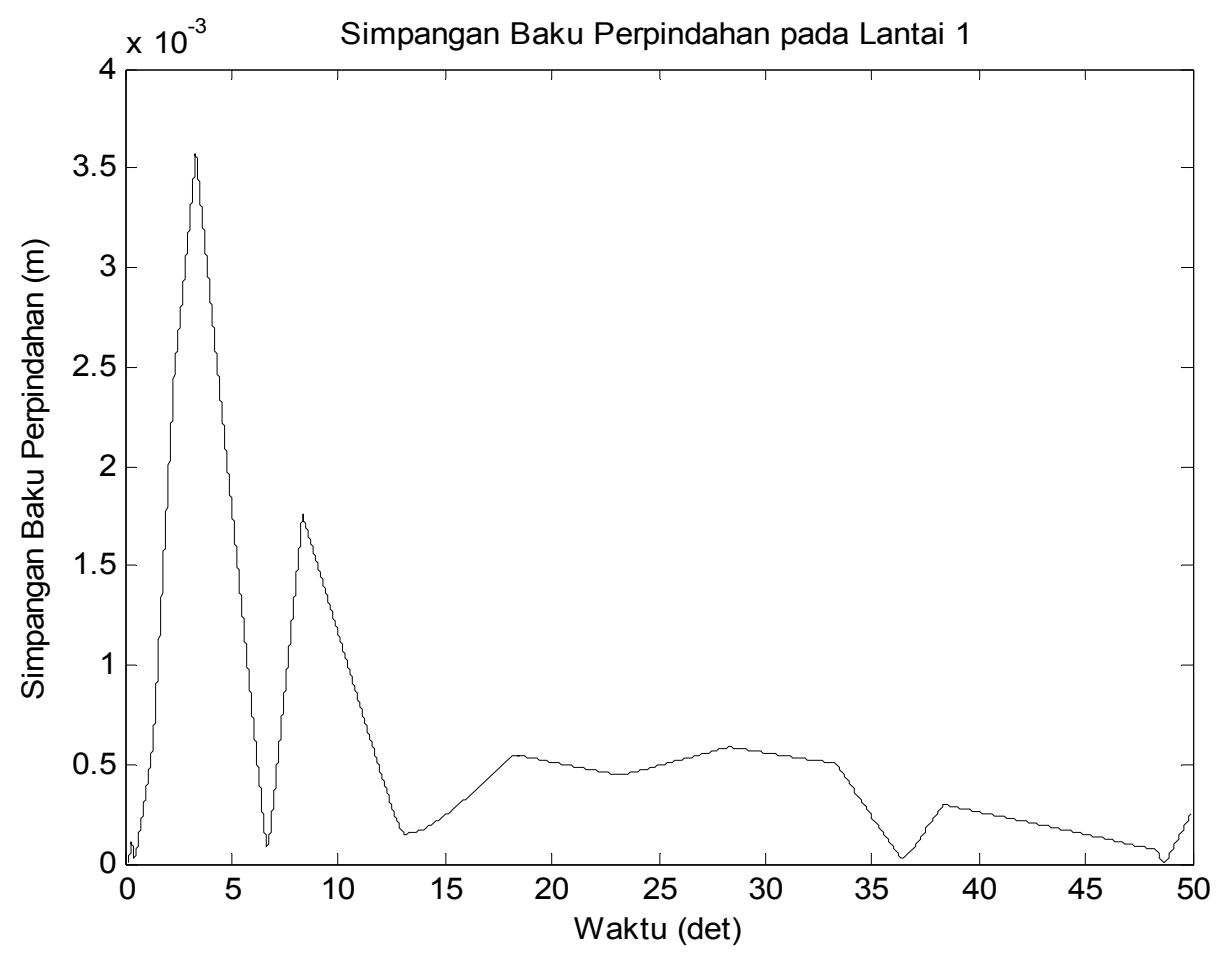

Gambar 5. Simpangan baku perpindahan di lantai 1 
Dengan memasukkan pengaruh paramater kekakuan sebagai faktor ketidakpastian diperoleh penambahan maksimum perpindahan di lantai 1 sebesar 0,18 \%.

Gambar 6 menunjukkan perpindahan lantai 2 terhadap riwayat waktu untuk orde pertama. Sedangkan Gambar 7 merupakan kontribusi perpindahan yang diperoleh dari orde dua di lantai 2. Simpangan baku perpindahan pada lantai 2 dapat dilihat pada Gambar 8. Tabel 2 menunjukkan hasil respon dinamik gedung lantai 2.

Tabel 2. Respons dinamik akibat beban gempa di lantai 2

\begin{tabular}{|c|c|c|}
\hline & $0^{\text {th }}($ meter $)$ & $2^{\text {th }}$ (meter) \\
\hline Mean & $2,2671 \times 10^{-5}$ & $-1,0885 \times 10^{-5}$ \\
\hline Simpangan Baku & 0,0274 & $3,6868 \times 10^{-5}$ \\
\hline Maksimum & 0,1464 & $1,7122 \times 10^{-4}$ \\
\hline
\end{tabular}

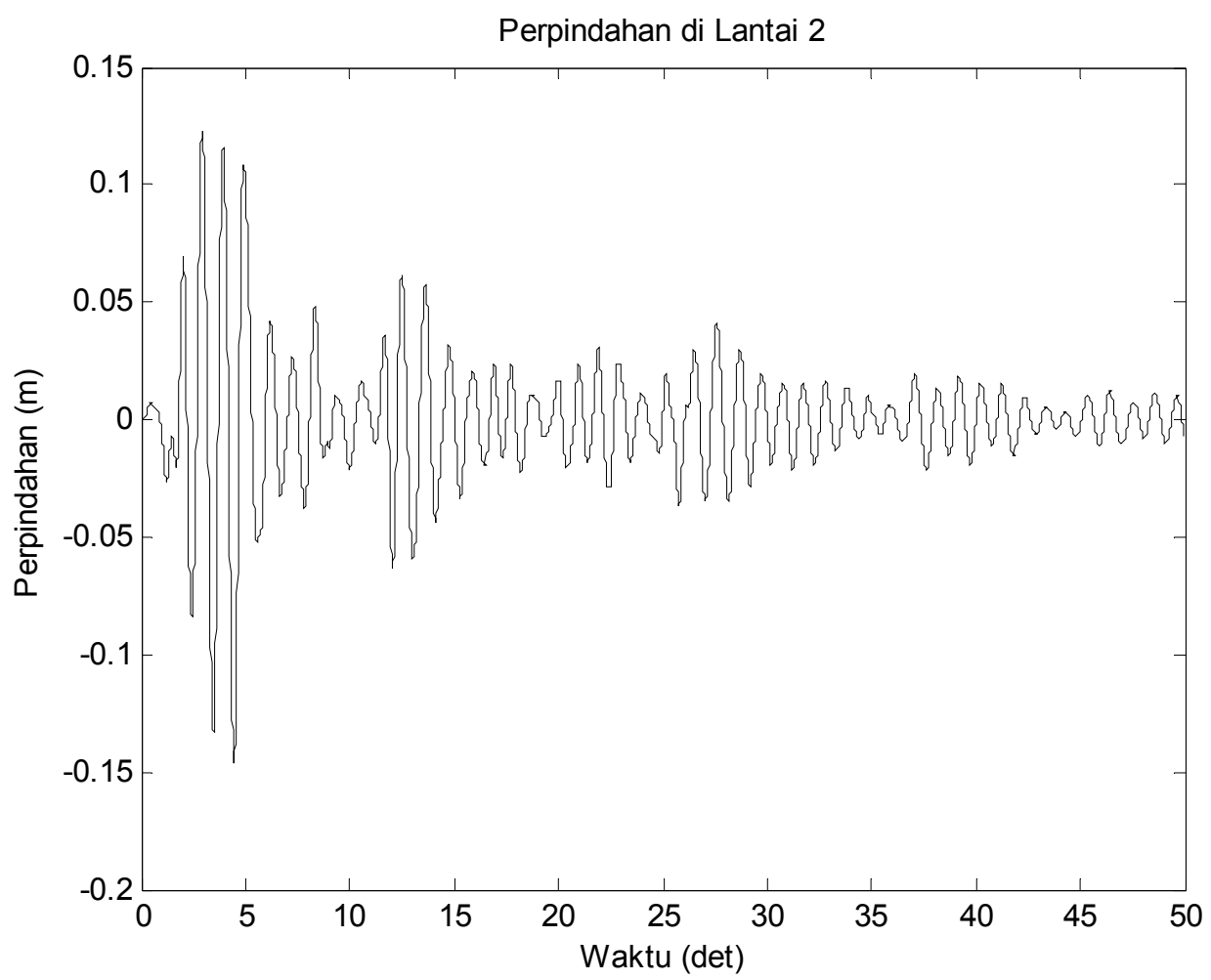

Gambar 6. Perpindahan lantai 2 terhadap riwayat waktu 


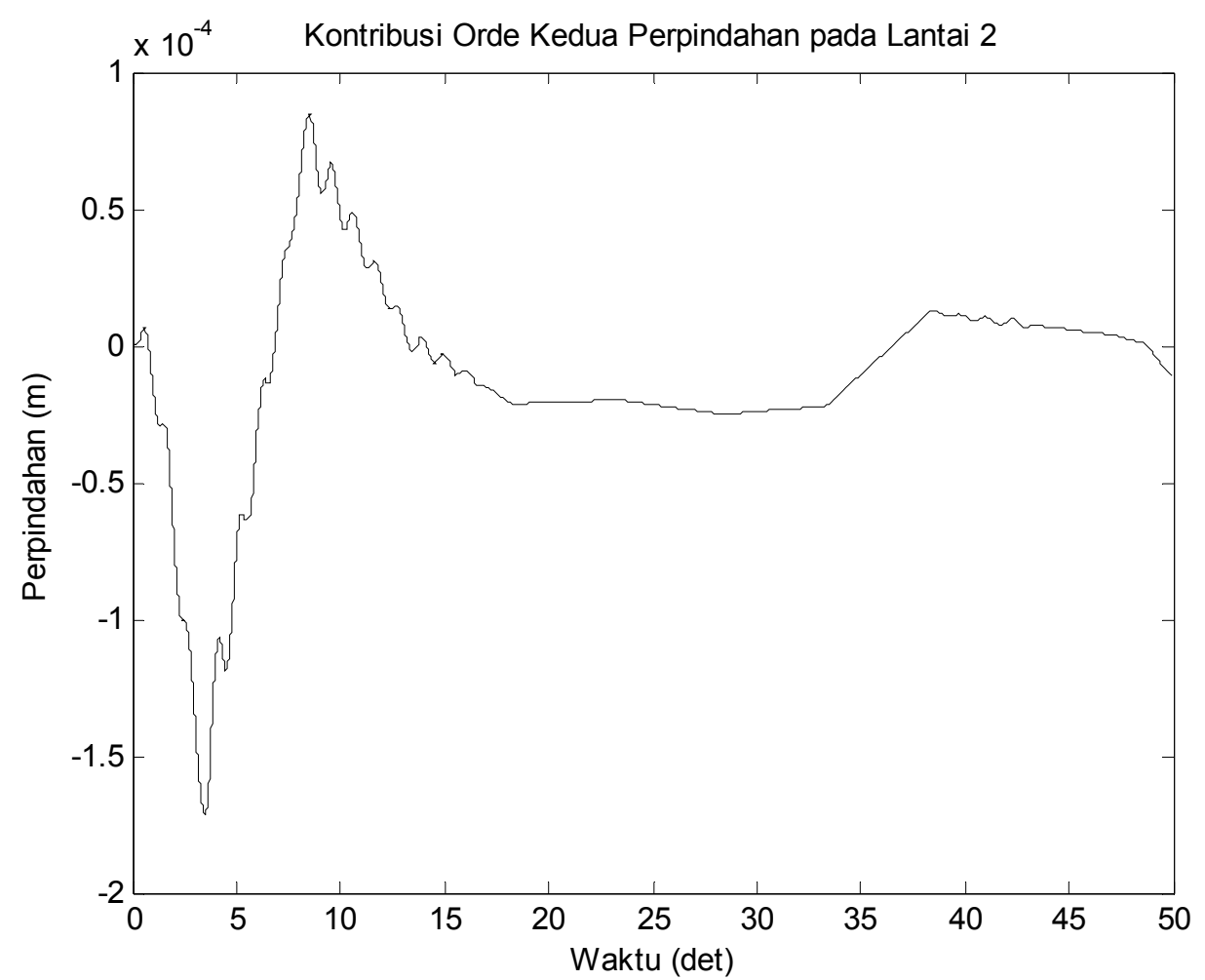

Gambar 7. Kontribusi orde kedua perpindahan di lantai 2

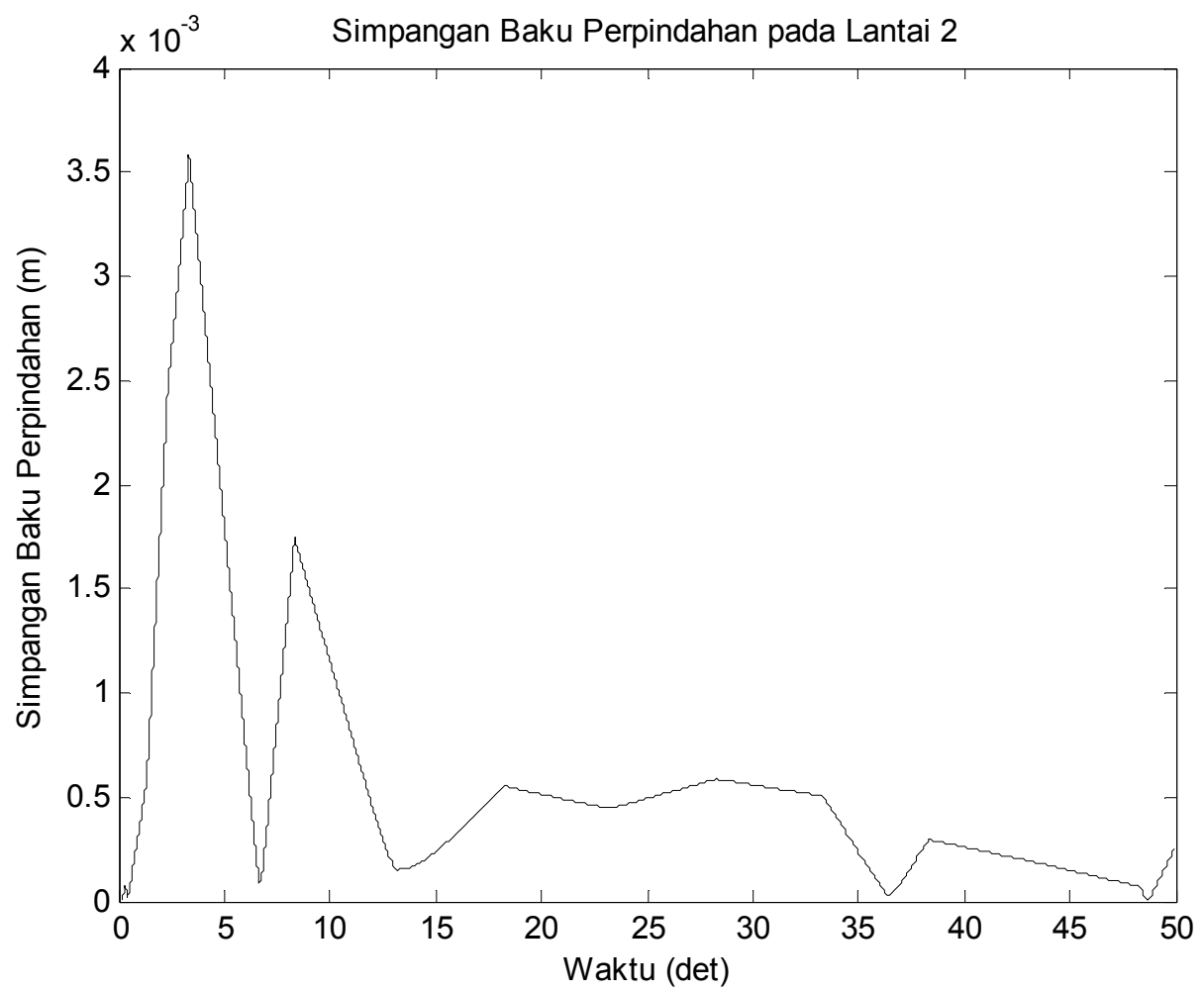

Gambar 8. Simpangan baku perpindahan di lantai 2 
Dengan memasukkan pengaruh paramater kekakuan sebagai faktor ketidakpastian diperoleh penambahan maksimum perpindahan di lantai 2 sebesar 0,12\%.

\section{KESIMPULAN}

Kesimpulan yang dapat diambil dari studi probabilitas respon struktur dengan metode elemen hingga ini, setelah diberikan beban gempa El-Centro serta peninjauan terhadap parameter ketidakpastian dimana kekakuan sebagai variansi parameternya, adalah sebagai berikut :

1. Pada lantai 1 terjadi adanya perubahan, yaitu adanya penambahan maksimum perpindahan sebesar $0,18 \%$.

2. Pada lantai 2 terjadi adanya perubahan, yaitu adanya penambahan maksimum perpindahan sebesar $0,12 \%$.

3. Dengan penambahan kekakuan sebagai parameter yang tidak pasti diperoleh penambahan perpindahan. Hal ini menjadi penting dalam menganalisa respon suatu struktur.

\section{DAFTAR PUSTAKA}

1. Astill, C.J., Nossier, S.B., and Shinozuka, M. (1972). "Impact loading on structures with random properties.” J. Struct. Mech., 1(1), 63-77.

2. Benjamin J.R., and Cornell, C.A. (1970), "Probability, Statistics, and Decision for Civil Engineers.” Penerbit Mc Graw - Hill, Inc, New York.

3. Chakraborty, S., and Dey, S.S. (1995). "Stochastic finite element method for spatial distribution of material properties and external loading." Comput. and Struct., 55(1), 41-45.

4. Clough, R. W., and Penzien, J.P. (1993). Dynamic of structures, 2nd ed., McGraw Hill, New York, NY.

5. Ghanem, R.G., and Kruger, R.M. (1996). "Numerical solution of spectral stochastic finite element systems." Comput. Methods Appl. Mech. Engrg., 129, 289-303.

6. Kaminski, M. (2002). "On probabilistic fatigue models for composite materials.” Int. J. Fatigue, 24, 477-495. 
7. Kleiber M., and Hien T. D. (1992), The Stochastic Finite Element Method., Basic Perturbation Technique and Computer Implementasi, Penerbit John Wiley and Sons, England.

8. Lee, B.W., and Lim, O.K. (1998). "Application of stochastic finite element method to optimal design of structures.” Comput. and Struct., 68, 491-497.

9. Lei, Z., and Qiu, C. (1998). "A dynamic stochastic finite element method based on dynamic constraint mode.” Comput. Methods Appl. Mech. Engrg., 161, 245-255.

10. Paz, M. (1990), Dinamika Struktur, Penerbit Erlangga, Indonesia.

11. Vanmarcke, M., and Grigoriu, M. (1983). "Stochastic finite element analysis of simple beam.” J. Eng. Mech, 109(5), 1203-1214.

[1] Olga Pattipawaej, Ph.D., Dosen Tetap, Jurusan Teknik Sipil, Fakultas Teknik, Universitas Kristen Maranatha Bandung. E-mail : olga.pattipawaej@eng.maranatha.edu

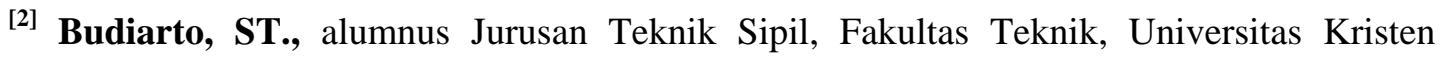
Maranatha, Bandung. 